\title{
PENGARUH VARIASI LUBANG PIRINGAN CAKRAM TERHADAP PELEPASAN PANAS PADA MOTOR MATIC 110 CC
}

\author{
EFFECT OF VARIATION OF HOLE DISC ON THE RELEASE OF HEAT IN \\ MOTOR MATIC 110 CC
}

Harum Tri Wahyudi ${ }^{1}$, Nely Ana Mufarida S.T., M.T. ${ }^{2}$, Kosjoko, S.T., M.T. ${ }^{3}$

\author{
${ }^{1}$ Mahasiswa, ${ }^{2}$ Dosen Pembimbing 1, ${ }^{3}$ Dosen Pembimbing 2, Program Studi Teknik Mesin, Fakultas \\ Teknik, Universitas Muhammadiyah Jember
}

Email: yoediboys@gmail.com

\begin{abstract}
ABSTRAK
Perkembangan sistem rem sepeda motor adalah adanya teknologi sistem rem cakram. Rem cakram merupakan pengembangan sistem rem tromol yang ada sebelumnya, dan banyak perbedaan antara jenis tersebut. Rem cakram sangat memudahkan bagi penggunanya dikarenakan kontruksi lebih sederhana dan lebih mudah perawatanya. Rem cakram pada dasarnya terdiri dari 3 komponen utama yaitu Piringan (Cakram), Kampas Rem dan, Caliper. Cakram adalah sebuah piringan logam yang cukup tipis dan digunakan untuk proses pengereman kendaraan. Hal ini dilakukan dengan memberikan gaya gesek pada bagian cakram tersebut.. Pada penelitian ini akan diambil data perbandingan antara piringan cakram dengan jumlah lubang 30; 36 dan 40. Dimana data tersebut meliputi kecepatan sepeda motor, beban pengereman, jarak tempuh,dan panas pada piringan. Metode pengukuran panas pada piringan dengan menggunakan thermometer yang pertama, dimulainya kecepatan $60 \mathrm{~km} / \mathrm{jam}$ dengan jarak $2 \mathrm{~km}$,dan dengan beban yang telah ditentukan sampai sepeda motor berhenti.dengan jumlah lubang 40, pelepasan panas pada piringan ini lebih cepat dan maksimal disbanding dengan piringan cakram dengan jumlah lubang 30 dan 36 . Pada temperatur awal ditemukan suhu rata-rata $25,13{ }^{\circ} \mathrm{C}$ dan pada temperatur panas menunjukan rata-rata pada $30,57^{\circ} \mathrm{C}$ dan untuk rata-rata pelepasan panas pada piringan dengan jumlah lubang 40 ditemukan 5,24 menit.

Kata kunci : Piringan cakram, pelepasan panas.
\end{abstract}

\begin{abstract}
Development of the brake system of motorcycle is the disc brake system technology. Disc brakes are drum brake systems development that existed before, and a lot of differences between the species. Disc brakes very easy for users because the construction is simpler and easier maintenant. Disc brakes basically consists of three main components, namely disc (discs), brake lining and, Caliper.The disc is a fairly thin metal plate and is used for braking the vehicle. This is done by giving the frictional force on the disc section .. In this study will be taken the comparison data between disk disc with a number of holes 30; 36 and 40. Where such data include the speed of the motorcycle, load braking, mileage, and heat on disc. The measurement method of heat to the dish by using a thermometer of the first, the start of a speed of $60 \mathrm{~km} / \mathrm{h}$ with a distance of $2 \mathrm{~km}$, and with a predetermined load to motorcycle brake number of holes 40, the release of heat on this disc more quickly and the maximum compared with disk disc with a number of holes 30 and 36. at the start temperature was found the average temperature and the temperature of hot $25,13{ }^{\circ} \mathrm{C}$ show on $30,57^{\circ} \mathrm{C}$ average and the average for the release of heat to the dish with a number of holes 40 found $5.24 \mathrm{~min}$.

Keywords: brake systems development, The Release Of Heat In
\end{abstract}

PENDAHULUAN

Pengaruh Unjuk.....Ariyanto
Sepeda motor merupakan salah satu produk otomotif kendaraan roda 2 yang banyak digunakan di 
Indonesia. Perkembangan terlihat dari segi banyaknya merek dan jumlah sepeda motor yang dipakai masyarakat. Hal ini terkait dengan penggunaan kendaraan tersebut di jalan, faktor keamanan dari pencurian dan resiko terhadap kecelakaan. Sehingga hal ini harus ditangani secara serius oleh berbagai pihak.

Salah satu komponen penting dalam sepeda motor adalah komponen pengereman. Sistem rem berfungsi untuk mengurangi kecepatan kendaraan dan menghentikan kendaraan tersebut. Hal ini dilakukan dengan memanfaatkan gesekan pada bagian roda yang berputar sehingga kecepatan putaran roda tersebut akan berkurang atau menjadi nol.

Perkembangan sistem rem sepeda motor adalah adanya teknologi sistem rem cakram. Rem cakram merupakan pengembangan sistem rem tromol yang ada sebelumnya, dan banyak perbedaan antara jenis tersebut. Rem cakram sangat memudahkan bagi penggunanya dikarenakan kontruksi lebih sederhana dan lebih mudah perawatanya. Rem cakram pada dasarnya terdiri dari 3 komponen utama yaitu Piringan (Cakram), Kampas Rem dan, Caliper. Cakram adalah sebuah piringan logam yang cukup tipis dan digunakan untuk proses pengereman kendaraan. Hal ini dilakukan dengan memberikan gaya gesek pada bagian cakram tersebut.

Gesekan yang terjadi pada cakram tergantung pada luas bidang kontak bahan karet yang digunakan sebagai penekan pada cakram. Cakram diberi lubanglubang untuk mengurangi berat cakram dan mempercepat pendinginan cakram tersebut. Hal ini dilakukan karena pada proses pengereman dengan gesekan akan menimbulkan panas.

\section{METODE PENELITIAN}

Penelitian pengaruh jumlah lubang pringan cakram terhadap pelepasan panas pada motor matic $110 \mathrm{cc}$ ini dilakukan diluar kampus dengan mengunakan alat satu set kunci yang dipergunakan untuk membongkar pasang pada komponen cakram dan roda pada sepeda motor. Pengujian dan penelitian ini dilakukan secara langsung diluar kampus,dan dengan melakukan pengujian dilapangan supaya mendapatkan hasil yang valid.

\section{Alat Dan Bahan Penelitian}

Penelitian rem akan menggunakan sepeda motor type 4 langkah motor matic $110 \mathrm{cc}$ yang sudah menggunakan diameter piringan cakram $190 \mathrm{~mm}$ engan jumlah lubang 30; 36 dan 40 (standard pabrik ).

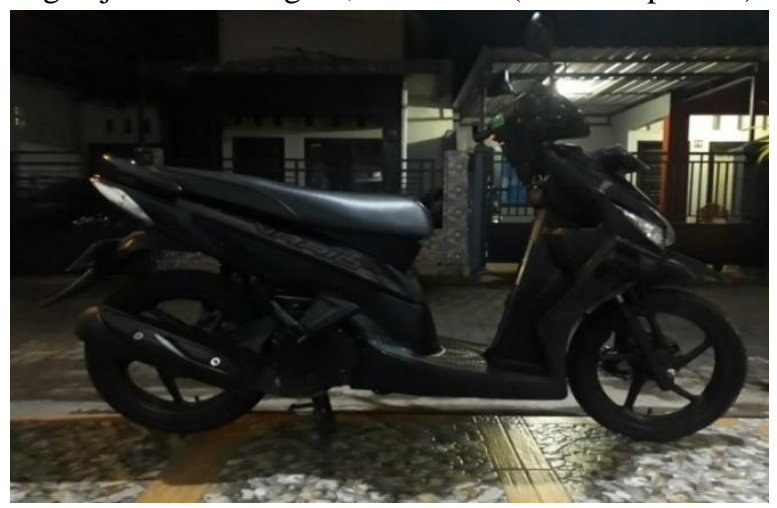

Gambar 1. Sepeda Motor yang Digunakan dalam Penelitian (dokumentasi pribadi) Tabel 1. Spesifikasi motor 110 CC

\begin{tabular}{|c|c|}
\hline Tipe & Vario CW \\
\hline Panjang X Lebar X Tinggi & $\begin{array}{l}1.897 \mathrm{~mm} \mathrm{X} 680 \mathrm{~mm} \\
\text { X } 1.083 \mathrm{~mm}\end{array}$ \\
\hline Jarak Sumbu Roda & $1.273 \mathrm{~mm}$ \\
\hline Jarak terendah ke tanah & $132.5 \mathrm{~mm}$ \\
\hline Berat kosong & $99,3 \mathrm{~kg}$ \\
\hline Kapasitas tangki bahan bakar & 3,6 liter \\
\hline Rangka & Tulang punggung \\
\hline Tipe suspensi depan & Teleskopik \\
\hline Tipe suspensi belakang & $\begin{array}{l}\text { Lengan ayun dengan } \\
\text { sokbreker tunggal }\end{array}$ \\
\hline Ukuran Ban Depan & $80 / 90$ - $14 \mathrm{M} / \mathrm{C} 40 \mathrm{P}$ \\
\hline Ukuran Ban Belakang & $90 / 90-14 \mathrm{M} / \mathrm{C} 46 \mathrm{P}$ \\
\hline Rem Depan & $\begin{array}{l}\text { Cakram hidrolik } \\
\text { dengan piston ganda }\end{array}$ \\
\hline Rem Belakang & Tromol \\
\hline Mesin & $\begin{array}{l}4 \text { langkah, SOHC } \\
\text { pendinginan dengan } \\
\text { cairan }\end{array}$ \\
\hline Kelas & 110 \\
\hline Volume Langkah & $108 \mathrm{cc}$ \\
\hline Diameter X Langkah & $50 \times 55 \mathrm{~mm}$ \\
\hline Perbandingan Kompresi & $10,7: 1$ \\
\hline Daya Maksimum & 8,99 PS/8.000 rpm \\
\hline Torsi Maksimum & $0,86 \mathrm{kgf.m} / 6.500 \mathrm{rpm}$ \\
\hline Tipe Transmsi & Otomatis V-Matic \\
\hline
\end{tabular}




\begin{tabular}{|l|l|}
\hline Tipe Starter & Pedal dan Elektrik \\
\hline Tipe Battery & $12 \mathrm{~V}-3,5 \mathrm{Ah}$ \\
\hline Busi & $\begin{array}{l}\text { ND U22FER9, NGK } \\
\text { CR7EH-9 }\end{array}$ \\
\hline Pengapian & DC-CDI, Baterai \\
\hline
\end{tabular}

\section{Piringan Cakram}

Dalam penelitian pelepasan panas disk brake pada sepeda motor $110 \mathrm{CC}$ perlu adanya penggantian piringan cakram dengan diameter piringan yang sama dan jumlah lubang piringan yang berbeda. Pada penelitian kali ini penulis menggunakan piringan dengan jumlah lubang 30; 36 dan 40 (standard pabrik). bahan yang sama (standart pabrik), dimana bahan tersebut adalah baja paduan rendah standar AISI 1045, JIS S45C, BS060A45, $100\left(\mathrm{~kg} / \mathrm{mm}^{2}\right)$, serta mengandung DIN C45 dengan kekuatan tarik unsur paduan antara lain, Carbon $(0,40-0,45 \%)$, phospor kurang dari nol (0).

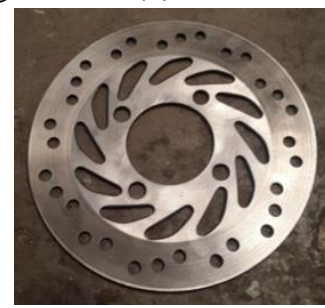

Gambar 2. Piringan dengan Jumlah 30 Lubang (dokumentasi pribadi)

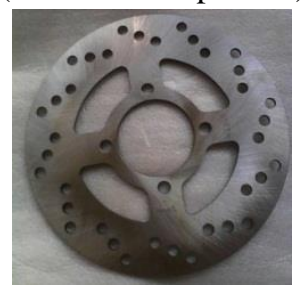

Gambar 3. Piringan dengan Jumlah 36 Lubang (dokumentasi pribadi)

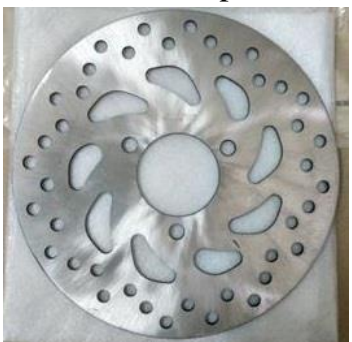

Gambar 4. Piringan dengan Jumlah 40 Lubang (dokumentasi pribadi)

\section{Caliper Rem}

Pada dasarnya dalam penelitian ini penulis masih menggunakan caliper sepeda motor $110 \mathrm{CC}$ strandard pabrik dengan menggunakan caliper dua piston pendorong kampas rem.

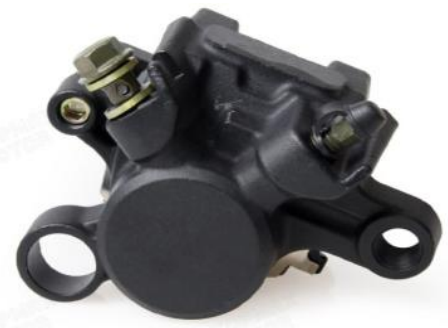

Gambar 5. Caliper Vario $110 \mathrm{cc}$ (dokumentasi pribadi)

\section{Minyak Rem}

Peran yang sangat penting dalam sistem pengereman hidraulik salah satunya adalah minyak rem,minyak rem berfungsi sebagai menyalurkan tekanan master rem ke caliper dan disambungkan ke kampas rem yang berfungsi mencekam piringan untuk memperlambat laju kendaraan. Minyak rem ada beragam jenis, pada umumnya sistem rem hidraulik sepeda motor menggunakan minyak rem jenis DOT 3 ,dengan rekomendasi pabrik, pada dasarnya minyak rem dibuat dari fermentasi tumbuhan dengan campuran bahan-bahan kimia.

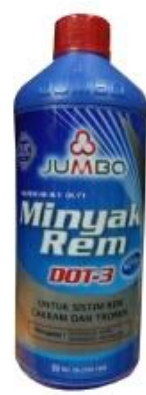

Gambar 6. Minyak Rem DOT 3

(dokumentasi pribadi)

4. Kunci tool seat

Dalam melakukan penetian ini perlu adanya kunci tool seat,guna untuk membongkar pasang piringan cakram pada sepeda motor.

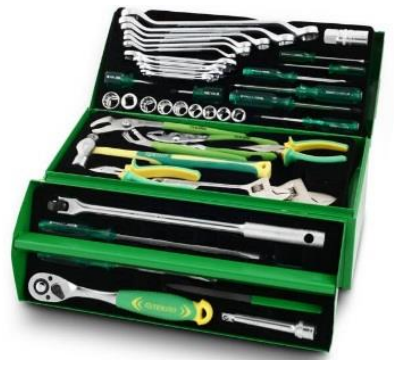

Gambar 7. Kunci Tool Seat (dokumentasi pribadi)

5. Thermometer 
Digunakan untuk mengukur berapa hasil panas dengan jarak dan beban yang telah direkomendasikan untuk penelitian. Spesifikasi Alat Pengukur Suhu Tembak Infrared Thermometer.

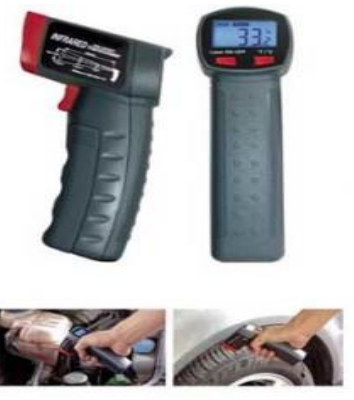

Gambar 8. Thermometer infrared (https://indo-digital.com/alat-pengukursuhu-tembak-infrared-thermometer-nonkontak-em520b.html)

6. Stopwatch

Digunakan untuk mengukur berapa lama waktu suhu panas over dan kembali ke suhu semula (dingin).

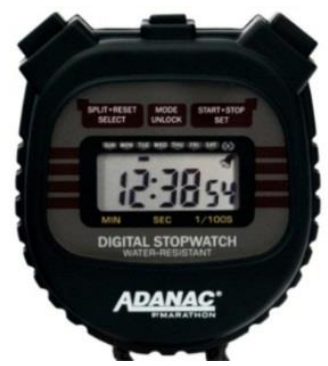

Gambar 9. Stopwatch/Alat Pengukur Kecepatan dan Waktu

(dokumentasi pribadi)

\section{Prosedur Penelitian}

Penelitian pelepasan panas pada piringan cakram akan menggunakan piringan sepeda motor matic 110 CC, dengan jumlah lubang 30; 36 dan 40 (standard pabrik). Dalam penelitian pelepasan panas pada piringan cakram ini telah tersusun rencana yang sudah diharapkan. Dalam pelaksanaan penelitian dilakukan beberapa tahap sebagai berikut, diantaranya:

1. Menyiapkan dan membeli alat serta bahan yang di butuhkan.

2. Mengganti piringan cakram pada setiap setelah dan selesai dalam pengambilan data.

\section{Metode Pengambilan Data}

Dalam perencanaan penelitian ini pada dasarnya dilakukan untuk mengetahui panas masing-masing piringan pada cakram dan memastikan piringan yang lebih baik dalam pelepasan panas. Penelitian dilakukan diluar kampus dengan mempertimbangkan jumlah lubang piringan. Pada penelitian ini akan diambil data perbandingan antara piringan cakram dengan jumlah lubang 30; 36 dan 40. Dimana data tersebut meliputi kecepatan sepeda motor, beban pengereman, jarak tempuh,dan panas pada piringan. Metode pengukuran panas pada piringan dengan menggunakan thermometer yang pertama,dimulainya kecepatan $60 \mathrm{~km} / \mathrm{jam}$ dengan jarak $2 \mathrm{~km}$,dan dengan beban yang telah ditentukan sampai sepeda motor berhenti.

\section{Analisis data}

Penelitian ini menggunakan teknik analisis deskriptif yaitu mengamati dan mencatat secara langsung hasil eksperimen kemudian menyajikan data dan menyimpulkan hasil penelitian yang telah dilakukan. Data yang dihasilkan yaitu meliputi tabel/grafik dari hasil penelitian yang berbentuk table kemudian ditampilkan kedalam bentuk grafik yang akan dianalisa dan ditarik kesimpulan sehingga dapat diketahui hasil dari perbandingan pelepasan panas dari masing-masing piringan cakram.

\section{HASIL DAN PEMBAHASAN Hasil Penelitian}

Berikut ini hasil penelitian dari pelepasan panas pada rem cakram dengan jumlah diameter $190 \mathrm{~mm}$ dan jumlah pada lubang piringan diantaranya 30; 36; 40 dengan ketebalan piringan $3 \mathrm{~mm}$. Pada penelitian ini masing masing piringan dengan mengambil 5 kali pengujian.

Tabel 2. Spesifikasi Piringan Cakram

\begin{tabular}{|c|c|c|c|}
\hline Diameter Piringan & Tebal Piringan & Jumlah Lubang & $\begin{array}{c}\text { Kecepatan dan } \\
\text { Jarak Tempuh }\end{array}$ \\
\hline $190 \mathbf{m m}$ & $3 \mathrm{~mm}$ & $\begin{array}{c}30 ; 36 ; 40 \text { lubang } \\
\text { (standart pabrik) }\end{array}$ & $60 \mathrm{~km} / \mathrm{j}(2 \mathrm{~km})$ \\
\hline
\end{tabular}

Hasil uji Piringan cakram dengan jumlah lubang 30

Tabel 3. Hasil Pengujian pada Jumlah Lubang 30

\begin{tabular}{|c|c|c|c|}
\hline \multicolumn{4}{|c|}{ Piringan cakram dengan jumlah lubang 30 } \\
\hline Pengujian & Temperatur awal ${ }^{\circ} \mathrm{C}$ & Temperatur akhir ${ }^{\circ} \mathrm{C}$ & $\begin{array}{c}\text { Waktu pelepasan panas } \\
\text { (menit) }\end{array}$ \\
\hline P1 & 27.5 & 34.5 & 7 \\
\hline P2 & 26.7 & 34.5 & 6.15 \\
\hline P3 & 27.7 & 34.1 & 6.5 \\
\hline P4 & 25.5 & 34.3 & 7.1 \\
\hline P5 & 27.1 & 34.5 & 6.7 \\
\hline rata - rata & 26.9 & 34.38 & 6.69 \\
\hline
\end{tabular}

Pada penelitian piringan cakram dengan jumlah lubang 30, tabel diatas menunjukkan bahwa pada suatu piringan dengan jumlah lubang yang sama akan menghasilkan temperatur akhir dan pelepasan panas dengan hasil yang berbeda. Berikut disajikan grafik 
perbandingan temperatur dan pelepasan panas pada jumlah lubang piringan 30 .

Piringan cakram dengan jumlah lubang 30

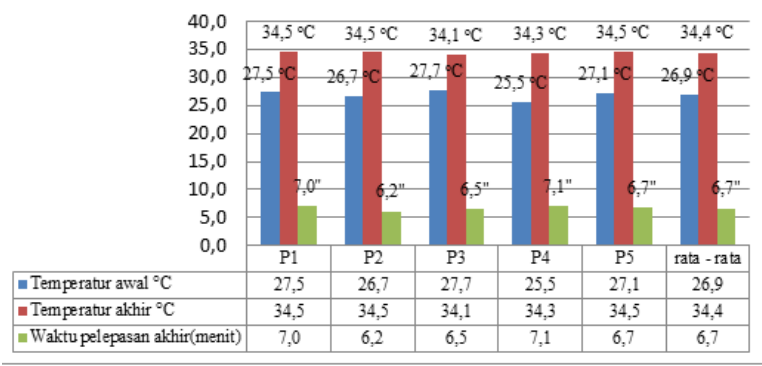

Gambar 10. Diagram Hasil Pengujian Piringan

Cakram Lubang 30

Hasil uji Piringan cakram dengan jumlah lubang 36

Tabel 4. Hasil Pengujian pada Jumlah Lubang 36

\begin{tabular}{|c|c|c|c|}
\hline \multicolumn{4}{|c|}{ Piringan cakram dengan jumlah lubang 36 } \\
\hline Pengujian & Temperatur awal ${ }^{\circ} \mathrm{C}$ & Temperatur akhir ${ }^{\circ} \mathrm{C}$ & $\begin{array}{c}\text { Waktu pelepasan panas } \\
\text { (menit) }\end{array}$ \\
\hline P1 & 26.4 & 32.2 & 6.22 \\
\hline P2 & 26.1 & 33.1 & 6 \\
\hline P3 & 26.5 & 33.2 & 6.5 \\
\hline P4 & 26.6 & 33.3 & 6.11 \\
\hline P5 & 26.8 & 33.3 & 6.5 \\
\hline rata - rata & 26.48 & 33.02 & 6.266 \\
\hline
\end{tabular}

Pada penelitian piringan cakram dengan jumlah lubang 30, tabel diatas menunjukkan bahwa pada suatu piringan dengan jumlah lubang yang sama akan menghasilkan temperatur panas dan pelepasan panas dengan hasil yang berbeda. Berikut disajikan grafik perbandingan temperatur dan pelepasan panas pada jumlah lubang piringan 30. Hasil uji pada penelitian piringan cakram lubang 36,pelepasan panas pada piringan ini lebih cepat dibanding dengan piringan cakram dengan jumlah lubang 30. Berikut disajikan grafik perbandingan temperatur dan pelepasan panas pada jumlah lubang piringan 36 .

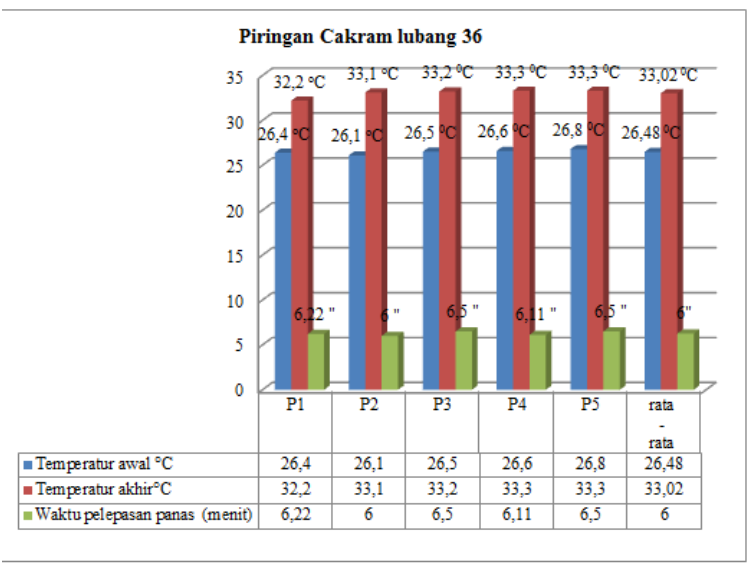

Gambar 11. Diagram Hasil Pengujian Piringan Cakram Lubang 36

\section{Hasil uji Piringan cakram dengan jumlah lubang 40}

Tabel 5. Hasil Pengujian pada Jumlah Lubang 40

\begin{tabular}{|c|c|c|c|}
\hline \multicolumn{4}{|c|}{ Piringan cakram dengan jumlah lubang 40} \\
\hline Pengujian & Temperatur awal ${ }^{\circ} \mathrm{C}$ & Temperatur akhir ${ }^{\circ} \mathrm{C}$ & $\begin{array}{c}\text { Waktu pelepasan panas } \\
\text { (menit) }\end{array}$ \\
\hline P1 & 26.1 & 31.3 & 5.35 \\
\hline P2 & 26.5 & 31.5 & 5.15 \\
\hline P3 & 26.1 & 31.1 & 5.31 \\
\hline P4 & 26.2 & 30.5 & 5.33 \\
\hline P5 & 26.3 & 31.3 & 5.15 \\
\hline rata - rata & 26.24 & 31.14 & 5.25 \\
\hline
\end{tabular}

Pada penelitian piringan cakram dengan jumlah lubang 40, tabel diatas menunjukkan bahwa pada suatu piringan dengan jumlah lubang yang sama akan menghasilkan temperatur panas dan pelepasan panas dengan hasil yang berbeda. Pada penelitian piringan cakram dengan jumlah lubang 40, pelepasan panas pada piringan ini lebih cepat dan maksimal dibanding dengan piringan cakram dengan jumlah lubang 30 dan 36. Berikut disajikan grafik perbandingan temperatur dan pelepasan panas pada jumlah lubang piringan 40 .

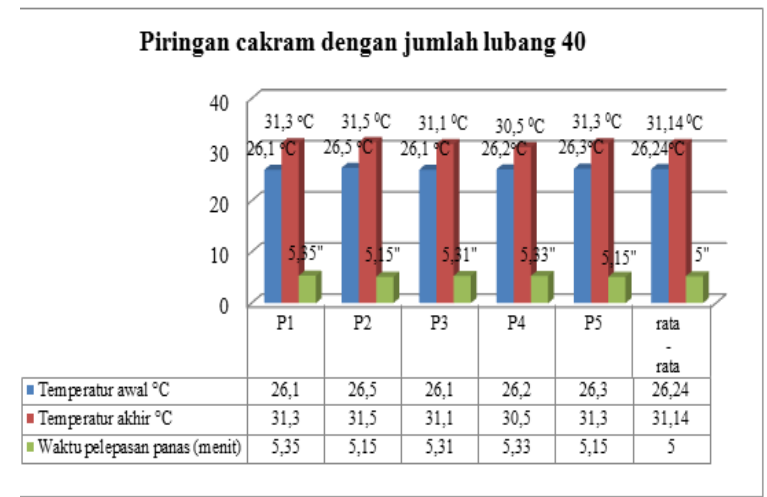

Gambar 12. Diagram Hasil Pengujian Piringan Cakram Lubang 40

\section{Analisa Dan Pengambilan Data}

Dari ketiga piringan tersebut masing-masing piringan menggunakan bahan yang sama (standart pabrik), dimana bahan tersebut adalah baja paduan rendah standar AISI 1045, JIS S45C, BS060A45, 100 $\left(\mathrm{kg} / \mathrm{mm}^{2}\right)$, serta mengandung DIN C45 dengan kekuatan tarik unsur paduan antara lain, Carbon $(0,40-0,45 \%)$, phospor kurang dari nol (0). Dimana dari ketiga piringan tersebut dapat diambil rata-rata :

- Pelepasan panas piringan dengan jumlah lubang 30:

Temperatur awal $\quad: 26,9^{\circ} \mathrm{C}$ 
Temperatur akhir

: $34,38^{\circ} \mathrm{C}$

Pelepasan panas

: 6,69 menit

Pada temperatur awal ditemukan suhurata-rata $26,9^{\circ} \mathrm{C}$ dan pada temperatur akhir menunjukan ratarata pada $34,38{ }^{\circ} \mathrm{C}$ dan untuk rata-rata pelepasan panas pada piringan dengan jumlah lubang 30 ditemukan 6,69 menit.

- Pelepasan panas piringan dengan jumlah lubang 36:

Temperatur awal

: $26,48^{\circ} \mathrm{C}$

Temperatur akhir

: $33,02^{\circ} \mathrm{C}$

Pelepasan panas

: 6,266 menit

Pada temperatur awal ditemukan suhu rata-rata $26,48{ }^{\circ} \mathrm{C}$ dan pada temperatur akhir menunjukan ratarata pada $33,26{ }^{\circ} \mathrm{C}$ dan untuk rata-rata pelepasan panas pada piringan dengan jumlah lubang 36 ditemukan 6,306 menit.

- Pelepasan panas piringan dengan jumlah lubang 40:

Temperatur awal

: $26,24^{\circ} \mathrm{C}$

Temperatur panas

: $31,14^{\circ} \mathrm{C}$

Pelepasan panas

: 5,258 menit

Pada temperatur awal ditemukan suhu rata-rata 26,24 ${ }^{\circ} \mathrm{C}$ dan pada temperatur akhir menunjukan ratarata pada $31,14{ }^{\circ} \mathrm{C}$ dan untuk rata-rata pelepasan panas pada piringan dengan jumlah lubang 40 ditemukan 5,258 menit.

\section{Pembahasan}

Dari data penelitian yang telah dilakukan, di dapatkan hasil untuk piringan jumlah lubang 30 membutuhkan waktu pelepasan panas 6,69 menit, dimana pada piringan jumlah lubang 36 membutuhkan waktu 6,306 menit, dan pada piringan dengan jumlah lubang 40 membutuhkan waktu 5,258 menit. Data diatas merupakan hasil uji dimana piringan dengan jumlah lubang 30,36 dan 40 dengan bahan standart pabrikmakadilakukan poses perbandingan menggunakan data pada table dibawah ini.

Tabel 6. Perbandingan Pelepasan Panas dari 3 Piringan Cakram

\begin{tabular}{cccc|}
$\begin{array}{c}\text { Jumla } \\
\mathbf{h} \\
\text { lubang }\end{array}$ & $\begin{array}{c}\text { Temperatu } \\
\mathbf{r} \text { awal }{ }^{\circ} \mathbf{C}\end{array}$ & $\begin{array}{c}\text { Temperatur } \\
\text { akhir }{ }^{\circ} \mathbf{C}\end{array}$ & $\begin{array}{c}\text { Waktu } \\
\text { pelepasan } \\
\text { panas } \\
\text { (menit) }\end{array}$ \\
\hline $\mathbf{3 0}$ & 26.9 & 34.48 & 6.69 \\
\hline $\mathbf{3 6}$ & 26.48 & 33.02 & 6.266 \\
\hline $\mathbf{4 0}$ & 26.24 & 31.14 & 5.258 \\
\hline
\end{tabular}

Dari pengambilan data diperoleh dari hasil $5 \mathrm{kali}$ proses pengujian pada motor "scooter matic" $110 \mathrm{cc}$ dan menunjukan perbandingan pelepasan panas pada 3 piringan cakram yang diambil rata- rata pada masing-masing piringan cakram.

Perhitungan perbandingan pelepasan panas pada piringan cakram pada motor matic $110 \mathrm{cc}$ dengan piringan cakram dengan jumlah lubang 30; 36 dan 40.

Perbandingan suhu temperature awal ${ }^{\circ} \mathrm{C}$ pada piringan cakram dengan jumlah lubang 30, 36, dan 40:

$$
\begin{aligned}
& =26.9+26.48+26.24 \\
& =\frac{79.62}{100 \%} \\
& =0.7962 \%
\end{aligned}
$$

Pada pengambilan data suhu awal pada masingmasing piringan cakram diperoleh hasil perbangdingan pada piringan cakram dengan jumlah lubang 30; 36 dan 40 dengan rata - rata awal pada setiap pirang cakram yaitu $26.9{ }^{\circ} \mathrm{C}, 26.48{ }^{\circ} \mathrm{C}$, dan $26.24{ }^{\circ} \mathrm{C}$ diketahui perbedaan suhu awal yaitu $0.7962 \%$.

Perbandingan suhu temperature panas ${ }^{\circ} \mathrm{C}$ pada piringan cakram dengan jumlah lubang 30; 36 dan 40:

$$
\begin{aligned}
& =34.38+33.02+31.14 \\
& =\frac{98.54}{100 \%} \\
& =0.9854 \%
\end{aligned}
$$

Pada pengambilan data suhu awal pada masingmasing piringan cakram diperoleh hasil perbangdingan pada piringan cakram dengan jumlah lubang 30; 36 dan 40 dengan rata - rata awal pada setiap pirang cakram yaitu $34.38^{\circ} \mathrm{C}, 33.02^{\circ} \mathrm{C}$, dan $31.14^{\circ} \mathrm{C}$ diketahui perbedaan suhu awal yaitu $0.9854 \%$.

Perbandingan waktu pelepasan panas pada piringan cakram dengan jumlah lubang 30; 36 dan 40:

$$
=6.69+6.266+5.258
$$

$=\frac{18.214}{100 \%}$

$$
=0.18214 \%
$$

Pada pengambilan data suhu awal pada masingmasing piringan cakram diperoleh hasil perbangdingan pada piringan cakram dengan jumlah lubang 30; 36 dan 40 (standard pabrik) dengan ratarata awal pada setiap pirang cakram yaitu $6.69^{\circ} \mathrm{C}$, $6.266{ }^{\circ} \mathrm{C}$, dan $5.258{ }^{\circ} \mathrm{C}$ diketahui perbedaan suhu 
awal yaitu $0.18214 \%$. Berikut grafik perbandingan pelepasan panas pada piringan cakram dengan jumlah lubang 30; 36 dan 40 (standard pabrik).

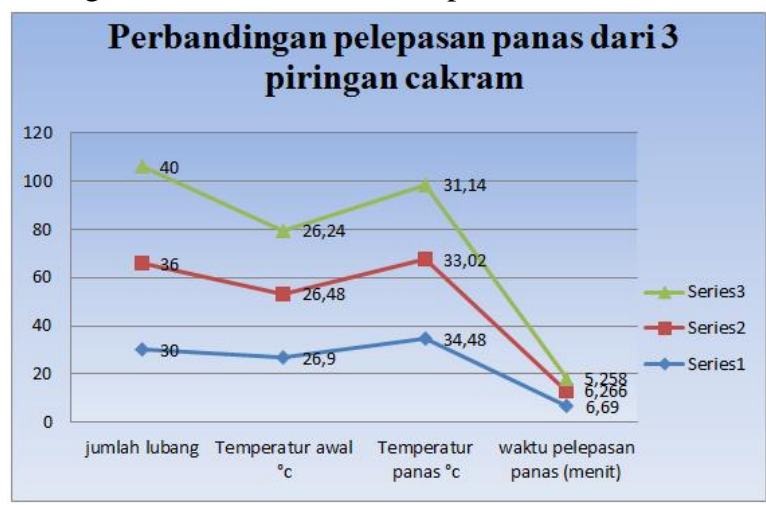

Gambar 13. Grafik Perbandingan Pelepasan

Panas pada 3 Piringan Cakram

A. Piringan cakram dengan jumlah lubang 30

Pada piringan cakram dengan jumlah lubang 30 dilakukan pengujian pada motor matic $110 \mathrm{CC}$ pada tempertur awal pada piringan cakram dengan rata-rata pada 5 kali pengujian yaitu $26,9{ }^{\circ} \mathrm{C}$ dan pada kecepatan $60 \mathrm{~km} / \mathrm{h}$ dengan jarak tempuh $2 \mathrm{~km}$ dihasil kan pada 3 kali pengujian dengan rata-rata suhu yang meningkat pada temperature $34,38^{\circ} \mathrm{C}$ dan waktu yang dibutuhkan untuk pelepasan panas pada pirangan cakram dengan jumlah lubang 30 pada 5 kali pengujian dengan rata-rata yaitu 6,69 menit.

B. Piringan cakram dengan jumlah lubang 36

Pada piringan cakram dengan jumlah lubang 36 dilakukan pengujian pada motor matic $110 \mathrm{CC}$ pada tempertur awal pada piringan cakram dengan rata-rata pada 5 kali pengujian yaitu $26,48{ }^{\circ} \mathrm{C}$ dan pada kecepatan $60 \mathrm{~km} / \mathrm{h}$ dengan jarak tempuh $2 \mathrm{~km}$ dihasilkan pada 5 kali pengujian dengan rata-rata suhu yang meningkat pada temperature $33,02{ }^{\circ} \mathrm{C}$ dan waktu yang dibutuhkan untuk pelepasan panas pada pirangan cakram dengan jumlah lubang 36 pada 3 kali pengujian dengan rata-rata yaitu 6,266 menit.

\section{Piringan cakram dengan jumlah lubang 40}

Pada piringan cakram dengan jumlah lubang 40 dilakukan pengujian pada motor matic $110 \mathrm{CC}$ pada tempertur awal pada piringan cakram dengan rata-rata pada 5 kali pengujian yaitu $26,24{ }^{\circ} \mathrm{C}$ dan pada kecepatan $60 \mathrm{~km} / \mathrm{h}$ dengan jarak tempuh $2 \mathrm{~km}$ dihasilkan pada 5 kali pengujian dengan rata-rata suhu yang meningkat pada temperature $31,14{ }^{\circ} \mathrm{C}$ dan waktu yang dibutuhkan untuk pelepasan panas pada pirangan cakram dengan jumlah lubang 36 pada 3 kali pengujian dengan rata-rata yaitu 5,258 menit.
Maka dihasilkan perbedaan temperature dan waktu pelepasan panas yang berbeda pada piringan cakram dengan jumlah lubang 30; 36 dan 40 (standard pabrik) pada proses pengereman pada saat perkendara padakecepatan $60 \mathrm{~km} / \mathrm{h}$ dengan jarak tempuh $2 \mathrm{~km}$ yang tidak bias ditentukan dengan kondisi jalan. Sedangkan untuk pengujian pelepasan panas pada setiap piringan cakram pada jumlah lubang 30; 36 dan 40 (standard pabrik) mengalami perbedaan yaitu pada jumlah lubang 30 pelasan panas yang dibutukan yaitu 6,73 menit, pada jumlah lubang 36 pelepasan panas yang dibutukan yaitu 6,11 menit, dan pada jumlah lubang 40 pelasan panas yang dibutukan 5,24 menit.

\section{PENUTUP}

\section{Kesimpulan}

Berdasarkan hasil dari penelitian yang telah dilakukan, maka dapat disimpulkan bahwa pelepasan temperatur panas pada piringan dengan jumlah lubang 30; 36 dan 40 (standard pabrik). Pada dasarnya semua jenis piringan pada sepeda motor menggunakan bahan yang relatif sama.

1. Dari penelitian keseluruhan, piringan cakram dengan jumlah lubang 40 , pelepasan panas pada piringan ini lebih cepat dibandingkan dengan piringan cakram dengan jumlah lubang 30 dan 36 . Pada temperatur awal ditemukan suhu rata-rata $25,13^{\circ} \mathrm{C}$ dan pada temperature akhir menunjukan rata-rata pada $30,57{ }^{\circ} \mathrm{C}$ dan untuk rata-rata pelepasan panas pada piringan dengan jumlah lubang 40 ditemukan 5,24 menit.

2. Dari penelitian dapat disimpulkan bahwa pelepasan panas yang lebih cepat adalah pada piringan cakram yang memiliki lebih banyak lubang dengan ketebalan dan diameter sama.

\section{Saran}

Di dalam penelitian piringan cakram sepeda motor 110 CC dengan jumlah lubang piringan 30; 36 dan 40, dan dengan diameter $190 \mathrm{~mm}$ ini masih terdapat banyak kekurangan, maka penulis memberikan saran sebagai berikut:

1. Perlu dilakukannya penelitian lebih lanjut tentang ketahanan atau kekuatan pada piringan cakram dari masing - masing jumlah lubang yang berbeda. 
2. Perlu ditambahkannya variasi diameter piringan cakram yang lebih besar atau dengan penambahan beban pada proses pengereman.

\section{DAFTAR PUSTAKA}

Dewanto joni dan wijaya Andreas. (2010). Sistem Pendingin Paksa Anti Panas Lebih (Over Heating) pada Rem Cakram (Disk Brake) Kendaraan, JURNAL TEKNIK MESIN Vol. 12, No. 2.

Dzikrullah Afrizal Annas, Qomaruddin, Khabib Masruki. (2017).Analisa Gesekan Pengereman Hidrolis (Rem Cakram) Dan Tromol Pada Kendaraan Roda Empat Dengan Menggunakan Metode Elemen Hingga.Universitas Muria Kudus Gondangmanis.

Multazam Ahmad, Zainuri Achmad, Sujita. (2012). Analisa Pengaruh Variasi Merek Kampas Rem Tromol Dan Kecepatan Sepeda Motor Honda Supra X125 Terhadap Keausan Kampas Rem. Jurusan Teknik Mesin, Fakultas Teknik, Universitas Mataram.

Rochmad, (2015), “Analisis Gaya Pengereman Pada Mobil Nasional Mini Truck" Jurnal, Jurusan Teknik Mesin, Universitas Muhammadiyah Surakarta.

Welianto Andre, (2010). "Pengaruh Keausan Brake Pad Terhadap Waktu Pengereman Pada Pengujian Stationer", Jurusan Teknik Mesin Univesitas Kristen Petra, Surabaya.

Siahaan Hardianto Ian, (2015). "Kinerja Rem Tromol Terhadap Kinerja Rem Cakram Pada Kendaraan Roda Dua Pada Pengujian Stasioner". Jurnal, Teknik Mesin Universitas Kristen Petra Surabaya. 